\title{
Activity of plant aqueous extracts on Bacillus thuringiensis and their interactions on Anticarsia gemmatalis (Lepidoptera: Erebinae)
}

\section{Atividade de extratos vegetais aquosos sobre Bacillus thuringiensis e a interação destes sobre Anticarsia gemmatalis (Lepidoptera: Erebinae)}

\author{
Andréia Vilani ${ }^{1}$; Everton Ricardi Lozano ${ }^{2 *}$; Michele Potrich²; \\ Luis Francisco Angeli Alves ${ }^{3}$; Fabiana Martins Costa Maia²; \\ Jackeline Dall Agnol de Lima ${ }^{4}$ Alfredo de Gouvea ${ }^{2}$
}

\begin{abstract}
The association of plant extracts and $B$. thuringiensis may be important in situations that control of different insects species is required and/or control of insects in various development stages. However, extracts may have different effects on $B$. thuringiensis, compromising their mode of action. Thus, the objective of this study was to evaluate the activity of aqueous plant extracts on Bacillus thuringiensis subsp. kurstaki (Btk) and their interactions on Anticarsia gemmatalis (Lepidoptera: Erebinae). Cherry plant extracts (Eugenia uniflora), pepper (Capsicum baccatum), trumpet (Brugmansia suaveolens) and grape japan (Hovenia dulcis), were used at $5 \%$ concentrations. For compatibility studies, the extracts were mixed with Thuricide ${ }^{\circledR}$ (Btk) and the parameters evaluated were Colony Formation Units (CFU $\mathrm{mL}^{-1}$ ) for spores and, the A. gemmatalis mortality for crystals. The cherry extracts, pepper, and japan grape completely inhibited the $\mathrm{CFU} \mathrm{ml}{ }^{-1}$ of Btk and the cherry extract alone negatively affected the toxicity of Btk crystals, with significantly lower mortality of $A$. gemmatalis $(20.40 \%)$ than that observed in the control with only Btk (79.44\%). In the association between cherry, pepper, and grape japan extracts with $B$. thuringiensis, the extracts exhibited a negative effect in the formation of CFU. The cherry extract demonstrated a negative effect on crystals action.
\end{abstract}

Key words: Entomopathogenic bacteria. Associated control. Botanical extracts.

\section{Resumo}

\begin{abstract}
A associação de extratos vegetais e $B$. thuringiensis pode ser importante em situações que em que se necessite controlar diferentes espécies de insetos-praga e ou insetos em diferentes fases de desenvolvimento. No entanto, os extratos podem apresentar diferentes efeitos sobre $B$. thuringiensis, comprometendo o seu modo de ação. Assim, o objetivo deste trabalho foi avaliar o efeito de extratos vegetais aquosos sobre Bacillus thuringiensis subesp. kurstaki (Btk) e a interação destes sobre Anticarsia gemmatalis (Lepidoptera: Erebinae). Foram utilizados extratos vegetais aquosos de pitanga (Eugenia
\end{abstract}

\footnotetext{
${ }^{1}$ M.e em Agronomia, Produção Vegetal, Universidade Tecnológica Federal do Paraná, UTFPR, Campus Pato Branco, PR, Brasil. E-mail: andreiavilani@yahoo.com.br

2 Profs. Drs., UTFPR, Campus Dois Vizinhos, PR, Brasil. E-mail: evertonloz@gmail.com; profmichele@gmail.com; fabeezoo@ gmail.com; alfredo@utfpr.edu.br

3 Prof. Dr., Universidade Estadual do Oeste do Paraná, UNIOESTE, Campus Cascavel, PR, Brasil. E-mail: luis.alves@unioeste.br

${ }^{4}$ Discente, Curso de Zootecnia, Bolsista Programa de Educação Tutorial, PET, Fundo Nacional da Educação, FNDE, Campus Dois Vizinhos, PR, Brasil. E-mail: jackelinedallagnol@gmail.com

* Author for correspondence
} 
uniflora), pimenta (Capsicum baccatum), trombeta (Brugmansia suaveolens) e uva-do-japão (Hovenia dulcis), na concentração de 5\%. Para estudar a comaptiilidade a B. thuringiensis, os extratos foram misturados com Thuricide ${ }^{\circledR}$ (Btk) e, os parâmetros avaliados foram unidades formadoras de colônia (UFC $\mathrm{mL}^{-1}$ ) para esporos e, para cristais, a mortalidade de A. gemmatalis. Os extratos de pitanga, pimenta e uva-do-japão inibiram totalmente a formação de UFC $\mathrm{mL}^{-1}$ de Btk e, apenas o extrato de pitanga afetou negativamente a toxicidade dos cristais de Btk, com redução significativa da mortalidade de $A$. gemmatalis (20,40\%), em relação à testemunha Btk $(79,44 \%)$. Na associação entre os extratos de pitanga, pimenta e uva-do-japão com $B$. thuringiensis estes interferem negativamente na formação de UFC e o extrato de pitanga apresenta efeito negativo para a ação dos cristais.

Palavras-chave: Bactéria entomopatogênica. Controle associado. Extratos botânicos.

Applied biological control with the use of entomopathogenic bacteria, mainly Bacillus thuringiensis Berliner (Bacillaceae) and the use of natural products such as plant extracts should be investigated for the control of insect pests, especially in alternative production systems. In general, the mode of action of Bacillus thuringiensis is dependent on the action of the spores and crystals in insects gut cells. It takes into account the solubilization steps of the crystal protein, the protease action in the activation of endotoxin and binding of toxins activated to specific receptors in the of insect midgut.

The secondary metabolites present in plants, among their other functions, can act as defensive agents against pathogens and herbivores attack, particularly insects (ISMAN, 2006) and may have acute and chronic insecticide effects, deterrence and repellence action, among others.

Bacillus thuringiensis may be used alone or associated with plant extracts for the control of insect pests (SILVA et al., 2012.). This association can be important, especially in situations that required control of different insects species and/or in various development stages. The association of plant extracts and $B$. thuringiensis may be synergistic, indifferent, or antagonistic. In the case of antagonism, chemicals can negatively affect entomopathogens, inhibiting vegetative growth and sporulation or even causing genetic mutations resulting in virulence decreased of the specific pests (ALVES et al., 1998). In turn, the synergistic interaction can cause a stressor effect on the insect pest, promoting high susceptible, to $B$. thuringiensis resulting in faster action of the pathogen or increasing insect mortality.

The association of the of $B$. thuringiensis with cypress extract, Taxodium distichum L. Rich (Taxodiaceae) increased virulence of the bacteria on insects of stored grains (SABBOUR, 2003).

The Myrtaceae and Solanaceae families stand out among the plants with insecticide potential due to the presence of alkaloids and limonoids, respectively, in their compounds, which have been known to have insecticidal effects. There are reports of Eugenia uniflora L (Myrtaceae) possessing compounds with insecticidal activity for the diamondback moth Plutella xylostella L. (Lep: Plutellidae) (TORRES et al., 2001) and Coleoptera (DEQUECH et al., 2008). In addition, there are records of compounds from Solanaceae species of the genera Capsicum with insecticidal effects on Coleoptera (DEQUECH et al., 2008) and Brugmansia genera on Haematobia irritans L. (Diptera: Muscidae) (CARRILLO et al., 2011).

Taking this into account and considering that the type and concentration of secondary metabolites may vary according to species and plant tissues used, the form of compounds extraction, the species and the target insect stage, studies aimed at the interaction of these with $B$. thuringiensis are important for the improvement and or development of insect pest control strategies. Thus, the objective of this study was to evaluate the effect of aqueous plant extracts on Bacillus thuringiensis subsp. 
kurstaki and the interaction of these on Anticarsia gemmatalis Hübner (Lepidoptera: Erebinae).

The bacteria used was Bacillus thuringiensis subsp. Kurstaki HD-1 strain $\left(30-52 \times 10^{6}\right.$ viable spores $\mathrm{mg}^{-1}$ ), formulated in the commercial product Thuricide $^{\circledR}$ WP $\left(32 \mathrm{~g} \mathrm{~kg}^{1}\right)$. The insect used as an indicator of the interaction was Anticarsia gemmatalis Hübner (Lepidoptera: Erebinae), obtained from those reared at the Biological Control Laboratory of the Universidade Tecnológica Federal do Paraná - Campus Dois Vizinhos (UTFPR-DV).

Obtaining plant extracts: Fruits of Capsicum baccatum var. pendulum Wild. (Solanaceae) (pepper), leaves of Eugenia uniflora L. (Myrtaceae) (Brazilian cherry), pseudofruits of Hovenia dulcis Thunb. (Rhamnaceae) (grape japan) and flowers of Brugmansia suaveolens Willd. (Solanaceae) (trumpet) were used to obtain the plant extracts. Samples were collected in the morning in Dois Vizinhos country, Paraná State Brazil, located in the third plateau of Paraná, $25^{\circ} 44^{\prime}$ South latitude and $54^{\circ} 04^{\prime}$ West longitude, at an altitude of $520 \mathrm{~m}$, with climate type, humid subtropical mesothermal (Cfa), according to the Köppen classification.

The collected material was dried at $40{ }^{\circ} \mathrm{C}$ for $48 \mathrm{~h}$ and a voucher specimen of each plant was forwarded to UTFPR-DV Herbarium for botanical identification and registration of the voucher copy. After drying, the material was ground in a knife mill (Willye type) to a particle size of up to $0.5 \mathrm{~mm}$. The $5 \%$ extracts were obtained by the addition of $5 \mathrm{~g}$ of the powder to $100 \mathrm{~mL}$ of sterile distilled water and left for $48 \mathrm{~h}$ in the dark at a temperature of $25 \pm 2$ ${ }^{\circ} \mathrm{C}$. The mixture was then filtered on a double filter paper in a Buckner funnel plugged into a Kitasato coupled to a constant pressure pump of $1.2 \mathrm{kgf} \mathrm{cm}^{-1}$.

Activity of Plant Aqueous Extracts on Spore Viability: A suspension at concentration $4.1 \times 10^{9}$ spores $\mathrm{mL}^{-1}$ was prepared by adding one gram of the Bacillus thuringiensis subsp. kurstaki (commercial product) to $10 \mathrm{~mL}$ of sterile distilled water. Thereafter, by serial dilutions a Btk suspension at the concentration of $4.1 \times 10^{5}$ spores $\mathrm{mL}^{-1}$ was prepared in sterile distilled water. Aliquots of 300 $\boldsymbol{\mu} \mathrm{L}$ of this suspension were added to Erlenmeyer flasks containing $50 \mathrm{~mL}$ of $5 \%$ plant extract. Four replicates were prepared for each extract in Erlenmeyer flasks (replicate seats) and placed in a horizontal shaker $\left(30 \pm 2{ }^{\circ} \mathrm{C}, 150 \mathrm{rpm}\right.$ for $\left.2 \mathrm{~h}\right)$. The suspension $\mathrm{pH}$ was measured before and at the end of the incubation. The mixture from each flask was inoculated at five points in two Petri dishes. Each of the five inoculations in each Petri dish consisted of $5 \mu \mathrm{L}$ of the mixture on the surface of a nutrient agar culture medium (AN). The plates were exposed in a laminar flux chamber for five minutes to allow evaporation of water excess and subsequently placed in a closed climatic chamber at $30 \pm 2{ }^{\circ} \mathrm{C}$ for $18 \mathrm{~h}$. These were then quantified for colony forming units (CFU) $\mathrm{mL}^{-1}$ per point. The control consisted of Btk in sterile distilled water.

Activity of Aqueous Plant Extracts on Crystals of B. thuringiensis subsp. kurstaki In Vivo: The suspensions with the mixtures of Btk and plant extracts and Btk alone were prepared in Erlenmeyer flasks containing $50 \mathrm{~mL}$ of $5 \%$ plant extracts and distilled water, respectively. In each flask 0.15 $\mathrm{g}$ of commercial product was added; equivalent to an application of $50 \mathrm{~g} \mathrm{ha}^{-1}$ in $100 \mathrm{~L} \mathrm{H}_{2} \mathrm{O}$. This dosage was previously established and promote approximately $80 \%$ mortality of $A$. gemmatalis larvae. After addition of Btk, the flasks were placed in a horizontal shaker and $\mathrm{pH}$ was determined as described previously. Then $150 \mu \mathrm{L}$ aliquots of the suspensions were added over $1.5 \mathrm{~cm}$ of the side surface of $A$. gemmatalis artificial diet cube, in four Petri dishes per treatment. Each plate (replication) received three diet cubes and 20 second instar caterpillars of $A$. gemmatalis. The plates were then conditioned in a climatized chamber $\left(27 \pm 2{ }^{\circ} \mathrm{C}, \mathrm{RH}\right.$ $70 \% \pm 10 \%$ and photoperiod $14 \mathrm{~h}$ ). The treatments consisted of the extracts, Btk alone, the mixture of extracts, Btk, and sterile distilled water (control). The evaluations were conducted at 24, 48 and $72 \mathrm{~h}$, quantifying the number of dead caterpillars. 
In both experiments the data were subjected to the Shapiro-Wilk test for normality and, when necessary, transformed into $(x+0.5) 1 / 2$ for spores and arcsine (arcsine (radix $(\times / 100))$ ) to crystals. Data were submitted to analysis of variance ( $\mathrm{F}$ test) and the averages compared using the Tukey's test $(\mathrm{p}<0.05)$, with the assistance of statistical program Bioestat $5.0^{\circledR}$. In the experiment with spores, the data was applied to the equation: for calculating extracts effect on spores, with negative and positive values, respectively, for determining increase or reduction of $\mathrm{CFU} \mathrm{mL}^{-1}$, as compared to the control.

It was found that pepper, cherry and grape japan extracts reduced the CFU mL ${ }^{-1}$ by $100 \%$. However, the trumpet extract showed $21.50 \%$ reduction in the number of CFU mL-1, which did not differ significantly from the control (Table 1).

Table 1. Mean ( \pm SE) CFU mL ${ }^{-1}$ of Bacillus thuringiensis subsp. kurstaki, after incubation with sterile distilled water and plant extracts $(5 \%)$, inoculated in a Petri dish containing nutrient agar culture medium and incubated in a climatic chamber $\left(30 \pm 2{ }^{\circ} \mathrm{C}\right.$ for $\left.18 \mathrm{~h}\right)$ and initial and final $\mathrm{pH}$ values.

\begin{tabular}{ccccc}
\hline \multirow{2}{*}{ Treatments } & \multirow{2}{*}{ Mean CFU $/ \mathrm{mL}\left(\times 10^{5}\right)$} & \multirow{2}{*}{ CFU Rel. Test $(\%)^{1}$} & $0 \mathrm{~h}$ & $\mathrm{pH}$ \\
\cline { 3 - 5 } Control & $3.35 \pm 1.91 \mathrm{a}$ & -- & 7.16 & 6.85 \\
Trumpet & $2.63 \pm 0.15 \mathrm{a}$ & -21.50 & 4.86 & 4.76 \\
Pepper & $0.00 \pm 0.00 \mathrm{~b}$ & -100.00 & 5.16 & 5.05 \\
Brazilian cherry & $0.00 \pm 0.00 \mathrm{~b}$ & -100.00 & 4.45 & 4.32 \\
Grape japan & $0.00 \pm 0.00 \mathrm{~b}$ & -100.00 & 4.96 & 5.80 \\
\hline $\mathrm{p}$ & 0.0004 & & &
\end{tabular}

Transformed data $(x+0.5) 1 / 2$. Mean $( \pm$ SE) followed by the same letter in the column do not differ significantly by Tukey's test $(\mathrm{P}<0.05) .{ }^{1}$ Percentage of colony forming units compared to the control.

The negative effects obtained for all extracts, may be due to the acidic $\mathrm{pH}$, since in all the treatments, the $\mathrm{pH}$ values were lower than observed in the control, ranging between 4.32 in the Brazilian cherry and 5.80 in grape japan. In a previous study on the germination of Bt spores in soil with different $\mathrm{pH}$, it was observed that the greater the acidity of the soil, the greater was the reduction in the germination of the spores, and below pH 5 germination ceased completely (PETRAS; CASIDA JUNIOR, 1985). Along with the possible effect of $\mathrm{pH}$, the reduction of CFU mL $\mathrm{mL}^{-1}$ could also be related to the compounds in the extracts, which could also cause deleterious effects on the spores. According to Silva et al. (2012) the secondary metabolites found in the extracts can prevent spore germination or destroy the bacterial membrane after germination. This could have been a possibility in this study.
Alkaloids are present as the main secondary metabolites in pepper extract (ALVES et al., 2007). In a study with pepper, Capsicum baccatum L. (Solanaceae) the extract was observed to have antibacterial activity for both Gram-negative and Gram-positive bacteria (CARVALHO et al., 2010), corroborating the results obtained in this study as Btk is Gram-positive.

The grape japan presents in its pseudofruits saponins, flavonoids and alkaloids (WANDSCHEER et al., 2011). Flavonoids are capable of inactivating extracellular proteins and cause disruption of the bacterial cell membrane (TSUCHIYA et al., 1996). Thus, it is inferred that in this study, Btk spores germinated in the mix with the extracts, but the bacterial membrane was destroyed because of its contact with them. 
As for the Brazilian cherry, the main phytochemicals found in its leaves are flavonoids and tannins (AURICCHIO et al., 2007). The antimicrobial properties of tannins are related to their ability to bind to proteins and enzymes, inactivating them as well as inhibiting oxidative phosphorylation in cellular respiration and causing the complexation of metal ions essential for some microorganisms (SCALBERT, 1991). In this case, besides the action of flavonoids described earlier for bacteria, tannins may have acted on the cells of Btk after germination, preventing the oxidative phosphorylation.

The results observed in this work for the trumpet extract corroborate with Schmidt et al. (2009) who found that the ethanolic and hexanic extracts of this plant did not inhibit the growth of Bacillus subtilis in the agar diffusion test. The main compounds found in B. suaveolens are tropanic alkaloids (e.g., scopolamine) that act in defense against herbivores (ALVES et al., 2007), and show a hallucinogenic effect on humans. From this it is inferred that the reduction in $\mathrm{CFU} \mathrm{mL} \mathrm{mL}^{-1}$ observed for the trumpet extract in the cited work is due to the acidic $\mathrm{pH}$ effect which reduced the germination percentage of spores.

Regarding the effect of Aqueous Plant Extracts on Crystals of B. thuringiensis subsp. kurstaki in vivo, $i$ was found that the pepper, grape japan and trumpet extract did not show a negative effect on the toxicity of the crystals, because the cumulative mortality of $A$. gemmatalis for the mixtures did not differ significantly from that of Btk alone. However, the Brazilian cherry extract mixed with Btk inhibited the action of protein crystals, because there was a significant reduction in cumulative mortality of larvae of $A$. gemmatalis (20.40\%), compared with Btk alone (79.44\%) (Table 2).

The negative effect of Brazilian cherry extract on the activity of the crystal protein may be related to the constituent compounds of this extract, mainly the tannins. According to Lord and Undeen (1990), tannins have the ability to bind to proteins of $B$. thuringiensis especially $\delta$-endotoxins and enzymes, and may cause efficiency loss.

Anticarsia gemmatalis mortality of showed no significant difference in the replicates with only extracts at all time intervals. However, for Btk, the highest percentages of $A$. gemmatalis mortality were observed at $48 \mathrm{~h}$ and $72 \mathrm{~h}$, a characteristic of the pathogen mode of action. Similarly, in the mixture of Btk with trumpet and grape japan extracts, highs $A$. gemmatalis mortality percentages was observed at $48 \mathrm{~h}$ and $72 \mathrm{~h}$, with no significant difference between them, suggesting that the extracts do not affect the toxicity of the crystals to A. gemmatalis (Table 2). In contrast, in the mixture of Brazilian cherry extract with Btk, there was no negative effect of the extract on Btk mode of action, reducing mortality of $A$. gemmatalis (19.08\%) at 72 $\mathrm{h}$, differing significantly from Btk alone $(41.25 \%)$ in the same time period.

The mixture of pepper extract with Btk showed higher mortality of $A$. gemmatalis at $48 \mathrm{~h}$ (70.72\%), significantly differing from the replicate with Btk alone $(35.69 \%)$ for the same time period, indicating that the association is positive and increase insect mortality. It is possible that pepper extract has a debilitating effect on the insect, making it more susceptible to pathogen action.

Although plants aqueous extracts analyzed did not exhibited insecticidal effects on A. gemmatalis they have shown insecticidal effects as previously mentioned, on other insect species. Thus, the use of aqueous extracts of the plants studied in association with $B$. thuringiensis, except for the Brazilian cherry extract, could act as control agents for different insect species, without interfering with the toxicity of $B$. thuringiensis. Additional studies regarding the effect of spore association and the effect of plant extracts on insect mortality as well as their evaluation in the field, and on other species of insects, are important to validate the association of the control strategies studied. 
The Brazilian cherry, pepper, and grape japan extracts have a negative effect on Btk spores, because they inhibit $\mathrm{CFU} \mathrm{mL}^{-1}$. In addition, the
Brazilian cherry extract has a negative effect on the toxicity of Btk crystals, reducing the mortality of $A$. gemmatalis.

Table 2. Mean Percentage ( \pm SE) mortality of caterpillars, second- instar Anticarsia gemmatalis, caused by plant extracts $(5 \%)$ and mixed with Bacillus thuringiensis subsp. kurstaki at different times and cumulative mortality after incubation. Determined initial and final pH. Temperature $27 \pm 2{ }^{\circ} \mathrm{C}, 14 \mathrm{~h}$ photoperiod and U.R. $70 \pm 10 \%$.

\begin{tabular}{|c|c|c|c|c|c|c|c|}
\hline \multirow{2}{*}{ Treatment } & \multicolumn{3}{|c|}{ Time h } & \multirow{2}{*}{$\begin{array}{c}\text { Cumulative } \\
\text { mortality }\end{array}$} & \multirow{2}{*}{ p } & \multicolumn{2}{|c|}{ pH } \\
\hline & 24 & 48 & 72 & & & $\mathbf{O h}$ & $2 \mathrm{~h}$ \\
\hline Control & $2.50 \pm 2.50 \mathrm{Aa}$ & $1.25 \pm 1.25 \mathrm{Ab}$ & $0.00 \pm 0.00 \mathrm{Ab}$ & $3.75 \pm 3.75 b$ & 0.6100 & 8.14 & 8.53 \\
\hline Trumpet & $0.00 \pm 0.00 \mathrm{Aa}$ & $0.00 \pm 0.00 \mathrm{Ab}$ & $1.32 \pm 1.32 \mathrm{Ab}$ & $1.32 \pm 1.32 \mathrm{~b}$ & 0.4074 & 4.56 & 4.5 \\
\hline Btk $^{1}$ & $2.50 \pm 2.50 \mathrm{Ba}$ & $35.69 \pm 8.17 \mathrm{Aa}$ & $41.25 \pm 5.15 \mathrm{Aa}$ & $79.44 \pm 4.12 \mathrm{a}$ & 0.0007 & 7.12 & 6.96 \\
\hline Trumpet +Btk & $0.00 \pm 0.00 \mathrm{Ba}$ & $33.09 \pm 8.60 \mathrm{Aa}$ & $32.50 \pm 12.50 \mathrm{Aa}$ & $65.59 \pm 7.96 \mathrm{a}$ & 0.0002 & 4.6 & 4.54 \\
\hline $\mathbf{p}$ & 0.5912 & 0.0001 & 0.0001 & 0.0001 & & & \\
\hline Control & $2.50 \pm 2.50 \mathrm{Aa}$ & $1.25 \pm 1.25 \mathrm{Ab}$ & $0.00 \pm 0.00 \mathrm{Ac}$ & $3.75 \pm 3.75 b$ & 0.6100 & 8.14 & 8.53 \\
\hline Brazilian cherry & $2.50 \pm 1.44 \mathrm{Aa}$ & $0.00 \pm 0.00 \mathrm{Ab}$ & $1.25 \pm 1.25 \mathrm{Ac}$ & $3.75 \pm 2.39 \mathrm{~b}$ & 0.3232 & 4.83 & 4.78 \\
\hline Btk & $2.50 \pm 2.50 \mathrm{Ba}$ & $35.69 \pm 8.17 \mathrm{Aa}$ & $41.25 \pm 5.15 \mathrm{Aa}$ & $79.44 \pm 4.12 \mathrm{a}$ & 0.0007 & 7.12 & 6.96 \\
\hline Brazilian cherry+Btk & $1.32 \pm 1.32 \mathrm{Ba}$ & $0.00 \pm 0.00 \mathrm{Bb}$ & $19.08 \pm 6.99 \mathrm{Ab}$ & $20.40 \pm 7.55 \mathrm{~b}$ & 0.0024 & 4.87 & 4.85 \\
\hline p & 0.9582 & 0.0001 & 0.0001 & 0.0001 & & & \\
\hline Control & $2.50 \pm 2.50 \mathrm{Aa}$ & $1.25 \pm 1.25 \mathrm{Ac}$ & $0.00 \pm 0.00 \mathrm{Ac}$ & $3.75 \pm 3.75 b$ & 0.6100 & 8.14 & 8.53 \\
\hline Pepper & $0.00 \pm 0.00 \mathrm{Aa}$ & $1.25 \pm 1.25 \mathrm{Ac}$ & $0.00 \pm 0.00 \mathrm{Ac}$ & $1.25 \pm 1.25 \mathrm{~b}$ & 0.5926 & 5.36 & 5.38 \\
\hline Btk & $2.50 \pm 2.50 \mathrm{Ba}$ & $35.69 \pm 8.17 \mathrm{Ab}$ & $41.25 \pm 5.15 \mathrm{Aa}$ & $79.44 \pm 4.12 \mathrm{a}$ & 0.0007 & 7.12 & 6.96 \\
\hline Pepper +Btk & $3.75 \pm 2.39 \mathrm{Ca}$ & $70.72 \pm 5.55 \mathrm{Aa}$ & $19.14 \pm 4.62 \mathrm{Bb}$ & $93.62 \pm 3.80 \mathrm{a}$ & 0.0001 & 5.4 & 5.4 \\
\hline $\mathbf{P}$ & 0.6021 & 0.0001 & 0.0001 & 0.0001 & & & \\
\hline Control & $2.50 \pm 2.50 \mathrm{Aa}$ & $1.25 \pm 1.25 \mathrm{Ab}$ & $0.00 \pm 0.00 \mathrm{Ab}$ & $3.75 \pm 3.75 b$ & 0.6100 & 8.14 & 8.53 \\
\hline Grape japan & $0.00 \pm 0.00 \mathrm{Aa}$ & $0.00 \pm 0.00 \mathrm{Ab}$ & $0.00 \pm 0.00 \mathrm{Ab}$ & $0.00 \pm 0.00 \mathrm{~b}$ & 0.8418 & 5.59 & 6.01 \\
\hline Btk & $2.50 \pm 2.50 \mathrm{Ba}$ & $35.69 \pm 8.17 \mathrm{Aa}$ & $41.25 \pm 5.15 \mathrm{Aa}$ & $79.44 \pm 4.12 \mathrm{a}$ & 0.0007 & 7.12 & 6.96 \\
\hline Grape japan +Btk & $1.25 \pm 1.25 \mathrm{Ba}$ & $38.33 \pm 1.67 \mathrm{Aa}$ & $32.08 \pm 1.25 \mathrm{Aa}$ & $71.67 \pm 2.04 \mathrm{a}$ & 0.0001 & 5.68 & 6.02 \\
\hline $\mathbf{P}$ & 0.7868 & 0.0001 & 0.0001 & 0.0188 & & & \\
\hline
\end{tabular}

Mean $( \pm \mathrm{SE})$ followed by the same letter in the column do not differ significantly by Tukey's test $(\mathrm{P}<0.05) .{ }^{1}$ Bacillus thuringiensis subsp. Kurstaki.

\section{Acknowledgements}

We thank the National Council for Scientific and Technological Development (CNPq) and the Foundation for the Support of Scientific and Technological Development of Paraná (Araucaria Foundation) for provision of financial aid.

\section{References}

ALVES, M. N.; SARTORATTO, A.; TRIGO, J. R. Scopolamine in Brugmansia suaveolens (Solanaceae): defense, allocation, costs, and induced response. Journal of Chemical Ecology, New York, v. 2, n. 33, p. 297-309, 2007.

ALVES, S. B.; MOINO JUNIOR, A.; ALMEIDA, J. E. M. Produtos fitossanitários e entomopatógenos. In: ALVES, S. B. Controle microbiano de insetos. Piracicaba: FEALQ, 1998. cap. 8, p. 217-238. 
AURICCHIO, M. T.; BUGNO, A.; BARROS, S. B. M.; BACCHI, E. M. Atividade antimicrobiana e antioxidante e toxicidade de Eugenia uniflora. Latin American Journal of Pharmacy, Buenos Aires, v. 26, n. 1, p. 76-81, 2007.

CARRILlo, A. C. C.; MOLANO, C. E. R.; LÓPEZ, C. O. Efecto insecticida in vitro del extracto etanólico de algunas plantas sobre la mosca adulta Haematobia irritans. Revista Cubana de Plantas Medicinales, Habana, v. 16, n. 3, p. 216-226, 2011.

CARVALHO, H. H.; WIEST, J. M.; CRUZ, F. T. Atividade antibacteriana in vitro de pimentas e pimentões (Capsicum sp.) sobre quatro bactérias toxinfectivas alimentares. Revista Brasileira de Plantas Medicinais, Botucatu, v. 12, n. 1, p. 8-12, 2010.

DEQUECH, S. T. B.; SAUSEN, C. D.; LIMA, C. G.; EGEWARTH, R. Efeito de extratos de plantas com atividade inseticida no controle de Microtheca ochroloma Stal (Col.:Chrysomelidae), em laboratório. Biotemas, Florianópolis, v. 21, n. 1, p. 41-46, 2008.

ISMAN, M. B. Botanical insecticides, deterrents, and repellents in modern agriculture and an increasingly regulated world. Annual Review of Entomology, Palo Alto, v. 51, n. 1, p. 45-66, 2006.

LORD, J. C.; UNDEEN, A. Inhibition of the Bacillus thuringiensis var. israelensis toxins by dissolved tannins. Environmental Entomology, Annapolis, v. 19, n. 5, p. 1547-1551, 1990.

PETRAS, S. F.; CASIDA JUNIOR, L. E. Survival of Bacillus thuringiensis Spores in soil. Applied and Enviromental Microbiology, Washington, v. 50, n. 6, p. 1496-1501, 1985.

SABBOUR, M. Combined effects of some microbial control agents mixed with botanical extracts on some stored product insects. Pakistan Journal of Biological Sciences, Faisalabad v. 6, n. 1, p. 51-56, 2003.
SCALBERT, A. Antimicrobial properties of tannins. Phyfochemisrry, Netherlands, v. 30, n. 12, p. 3875-3883, 1991.

SCHMIDT, C.; FRONZA, M.; COETTERT, M.; GELlER, F.; LUIK, S.; FLORES, E. M. M.; BITTENCOURT, C. F.; ZANETTI, G. D.; HEINZMANN, B. M.; LAUFER, S.; MERFORT, I. Biological studies on Brazilian plants used in wound healing. Journal of Ethnopharmacology, Ireland, v. 122, n. 3, p. 523-532, 2009.

SILVA, E. R. L.; ALVES, L. F. A.; MARTINELO, L.; FROMENTINI, M. A.; MARCHESE, L. P. C.; PINTO, F. G. S.; POTRICH, M.; NEVES, P. M. O. J. Natural phytosanitary products effects on Bacillus thuringiensis subesp. kurstaki (Berliner). Semina: Ciências Agrárias, Londrina, v. 33, p. 2891-2904, 2012. Suplemento 1.

TORRES, A. L.; BARROS, R.; OLIVEIRA, J. V. Efeito de extratos aquosos de plantas no desenvolvimento de Plutella xylostella (L.) (Lepidoptera: Plutellidae). Neotropical Entomology, Londrina, v. 30, n. 1, p. 151$156,2001$.

TSUCHIYA, H.; SATO, M.; MIYAZAKI, T.; FUJIWARA, S.; TANIGAKI, S.; OHYAMA, T.; TANAKA, T.; LINUMA, M. Comparative study on the antibacterial activity of hytochemical flavanones against methicillin-resistant Staphylococcus aureus. Journal Ethnopharmacol, Ireland, v. 50, n.1, p. 27-34, 1996.

WANDSCHEER, A.; BORELLA, J.; BONATTI, L. C.; PASTORINI, L. H. Atividade alelopática de folhas e pseudofrutos de Hovenia dulcis Thunb. (Rhamnaceae) sobre a germinação de Lactuca sativa L. (Asteraceae). Acta Botanica Brasilica, Feira de Santana, v. 25, n. 1, p. 25-30, 2011. 
